\title{
The impact of theory-based messages on COVID-19 vaccination intentions: a structured summary of a study protocol for a randomised controlled trial
}

Ben Young ${ }^{1 *}$ (D), Marie Kotzur ${ }^{1}$, Lauren Gatting ${ }^{1}$, Carissa Bonner ${ }^{2}$, Julie Ayre ${ }^{2}$, Alex McConnachie ${ }^{1}$, Carys Batcup ${ }^{2}$, Kirsten McCaffery ${ }^{2}$, Ronan $\mathrm{O}^{\prime}$ Carroll ${ }^{3}$ and Kathryn A. Robb ${ }^{1}$

\begin{abstract}
Objectives: Uptake of vaccination against COVID-19 is key to controlling the pandemic. However, a significant proportion of people report that they do not intend to have a vaccine, often because of concerns they have about vaccine side effects or safety. This study will assess the impact of theory-based messages on COVID-19 vaccination intention, drawing on the Necessity-Concerns framework to address previously reported beliefs and concerns about COVID-19 vaccination, and assess whether hypothesised variables (illness coherence, perceived necessity and concerns) mediate change in vaccination intention.
\end{abstract}

Trial design: Prospective, parallel two-arm, individually randomised (1:1) trial.

Participants: Adults aged over 18 years, living in Scotland and not vaccinated for COVID-19. A quota sampling approach will be used with the aim of achieving a nationally representative sample on gender, region and ethnic group, with oversampling of individuals with no educational qualifications or with only school-level qualifications.

Intervention and comparator: Intervention: Brief exposure to online text and image-based messages addressing necessity beliefs and concerns about COVID-19 vaccination.

Comparator: Brief exposure to online text and image-based messages containing general information about COVID19 and COVID-19 vaccination.

Main outcomes: Primary outcome: Self-reported intention to receive a vaccine for COVID-19 if invited, immediately post-intervention. Secondary outcomes: Self-reported COVID-19 illness coherence, perceived necessity of a COVID19 vaccine and concerns about a COVID-19 vaccine, immediately post-intervention.

Randomisation: Quasi-randomisation performed automatically by online survey software, by creating a variable derived from the number of seconds in the minute that the participant initiates the survey. Participants starting the survey at 0-14 or 30-44 seconds in the minute are allocated to the intervention and 15-29 or 45-59 seconds to the comparator.

(Continued on next page)

\footnotetext{
*Correspondence: ben.young@glasgow.ac.uk

'University of Glasgow, Glasgow, UK

Full list of author information is available at the end of the article
}

(c) The Author(s). 2021 Open Access This article is licensed under a Creative Commons Attribution 4.0 International License, which permits use, sharing, adaptation, distribution and reproduction in any medium or format, as long as you give appropriate credit to the original author(s) and the source, provide a link to the Creative Commons licence, and indicate if changes were made. The images or other third party material in this article are included in the article's Creative Commons licence, unless indicated otherwise in a credit line to the material. If material is not included in the article's Creative Commons licence and your intended use is not permitted by statutory regulation or exceeds the permitted use, you will need to obtain permission directly from the copyright holder. To view a copy of this licence, visit http://creativecommons.org/licenses/by/4.0/ The Creative Commons Public Domain Dedication waiver (http://creativecommons.org/publicdomain/zero/1.0/) applies to the data made available in this article, unless otherwise stated in a credit line to the data. 
(Continued from previous page)

Blinding (masking): Participants will not be blinded to group assignment but will not be informed of the purpose of the study until they have completed the follow-up survey. Investigators will be blinded to allocation as all procedures will be undertaken digitally and remotely without any investigator contact with participants.

Numbers to be randomised (sample size): A total of 1,094 will be randomised 1:1 into two groups with 547 individuals in each.

Trial Status: Protocol version number 1.0, $26^{\text {th }}$ February 2021.

Recruitment status: Not yet recruiting, set to start April 2021 and end April 2021.

Trial registration: ClinicalTrials.gov, NCT04813770, 24 ${ }^{\text {th }}$ March 2021.

Full protocol: The full protocol is attached as an additional file, accessible from the Trials website (Additional file 1). In the interest in expediting dissemination of this material, the familiar formatting has been eliminated; this Letter serves as a summary of the key elements of the full protocol.

Keywords: COVID-19, randomised controlled trial, protocol, vaccination, vaccine hesitancy, messaging, NecessityConcerns Framework, illness beliefs, treatment beliefs

\section{Supplementary Information}

The online version contains supplementary material available at https://doi. org/10.1186/s13063-021-05277-7.

Additional file 1. Full study protocol.

\section{Acknowledgements}

Not applicable.

\section{Authors' contributions}

All authors were involved in the design of this trial, drafting the work or revising it critically for intellectual content, and have read and approved the final structured summary.

\section{Funding}

University of Glasgow USyd-Glasgow Partnership Collaboration Award. The funding body had no role in the design of the study or collection, analysis, and interpretation of data or in writing the manuscript.

\section{Availability of data and materials}

The trial dataset and materials will be made publicly available via the

Enlighten: Research Data repository https://www.gla.ac.uk/research/enlighten

\section{Declarations}

Ethics approval and consent to participate

University of Glasgow's College of Medical, Veterinary and Life Sciences Research Ethics Committee approved the study, ref. 200200052, 29 ${ }^{\text {th }}$ January 2021. The authors certify that this trial has received ethical approval from the appropriate ethical committee as described above. Consent will be obtained from all participants before entering into the study.

\section{Consent for publication}

Not applicable.

\section{Competing interests}

The authors declare that they have no competing interests.

\section{Author details}

${ }^{1}$ University of Glasgow, Glasgow, UK. ${ }^{2}$ University of Sydney, Sydney, Australia.

${ }^{3}$ University of Stirling, Stirling, UK.
Received: 7 April 2021 Accepted: 16 April 2021

Published online: 29 April 2021

\section{Publisher's Note}

Springer Nature remains neutral with regard to jurisdictional claims in published maps and institutional affiliations.
Ready to submit your research? Choose BMC and benefit from:

- fast, convenient online submission

- thorough peer review by experienced researchers in your field

- rapid publication on acceptance

- support for research data, including large and complex data types

- gold Open Access which fosters wider collaboration and increased citations

- maximum visibility for your research: over $100 \mathrm{M}$ website views per year

At BMC, research is always in progress.

Learn more biomedcentral.com/submissions 